\title{
Audit Committee Characteristics and Executive Committee Characteristics and Firm Performance in Oman: Empirical Study
}

\author{
Ebrahim Mohammed Al-Matari ${ }^{1}$, Abdullah Kaid Al-Swidi ${ }^{2} \&$ Faudziah Hanim Bt Fadzil $^{2}$ \\ ${ }^{1}$ Faculty of Business and Economics, Ammran University, Yemen and Othman Yeop Abdullah Graduate School \\ of Business, University Utara Malaysia, Malaysia \\ ${ }^{2}$ Othman Yeop Abdullah Graduate School of Business, University Utara Malaysia, Malaysia \\ Correspondence: Ebrahim Mohammed Al-Matari, Faculty of Business and Economics, Ammran University, \\ Yemen and Othman Yeop Abdullah Graduate School of Business, University Utara Malaysia, Malaysia. E-mail: \\ ibrahim_matri@yahoo.com
}

Received: December 29, 2013 Accepted: April 12, 2014 Online Published: May 26, 2014

doi:10.5539/ass.v10n12p98 URL: http://dx.doi.org/10.5539/ass.v10n12p98

\begin{abstract}
This study attempted to examine the association between two important committees of corporate governance practice namely, audit committee characteristics and executive committee characteristics, and firm performance. The data used comprised of non-financial companies listed in Muscat Security Market (MSM) through 2011 and 2012. Based on widely existing literature that studied the relationship between corporate governance and firm performance, studies that investigated the role of executive committee with firm performance are few and far between and hence, the main aim of this study is to discover this relation. Therefore, this study is an attempt to fill the gap in literature by exploring these new measures and contributing to a rich body of existing literature.

The outcome of this study revealed a positive relationship between audit committee size (ACSIZE), audit committee independence (ACINDE) and executive committee size (ECSIZE) and firm performance but not significant. In addition, the association between audit committee meeting (ACMEETIN), executive committee independence (ECINDE) and executive committee meeting (ECMEETIN) and firm performance was negative but not significant. The findings found the relationship between firm size (FIRMSIZE) and firm performance to be positively significant while the relationship between leverage (LEVERAG) and firm performance was found to be negatively significant. Finally, this study discusses the results and provides limitation and recommendations towards the end.
\end{abstract}

Keywords: corporate governance, audit committee characteristics, executive committee characteristics, performance and Oman

\section{Introduction}

With the advent of the Asian financial crisis in 1997 and 1998 and the recent crisis involving Enron, WorldCom, Ahold among others, in Europe and America, confidence on corporate institutions and legislative bodies \& agencies is all-time low. These problems were highlighted during the crisis including the operations and transactions in-house, staff, relatives and friends involved in businesses and government and companies receiving a significant amount of short-term debts without the knowledge of shareholders. These debts were concealed through the accounting methods and the systems of innovation. As a response to the collapse of some leading companies such as Enron, WorldCom and Ahold, deep investigations were conducted and showed that among the main reasons behind that disaster was the manipulation of their financial statements. As a result, great attention has been given to corporate governance as a mechanism that protects investors by ensuring proper management practices (Bøhren \& Strøm, 2010; Brown \& Caylor, 2006; Jackling \& Johl, 2009; Khanchel, 2007; Mokhtar et al., 2009).

The issue of corporate governance has become one of the most widespread and common themes in the business environment and investment in gulf countries. It has gained governance importance as a result of the following factors; enormous developments, its importance in the practice of the departments of companies, its significance in dealing with shareholders and the manner and method of preserving the rights of shareholders, and finally, various financial collapses and administrative major international companies, and the prevalence of financial and 
administrative corruption, which led to the collapse of major economies of the countries in the last decade (Al-Manaseer et al., 2012).

Corporate governance has become an issue in both business and academic world. The concern in the business world emanates from the perceived importance of moral and ethical conduct in business that creates general climate (environment, both legal and social) promoting good corporate governance. In academia, it was determined that business decisions are not made in a vacuum. Business decision makers have goals other than business objectives. For example, managers are interested about their personal satisfaction rather than their employees, as well as benefits of the community (society) in general. These objectives negatively impact the equity (Fama \& Jensen, 1983; Sheifer \& Vishny, 1997). The structures of corporate governance specify the distribution of rights and responsibilities among various stakeholders in a society, as the board, directors, shareholders and others, and clarify the rules and procedures for making decisions on corporate issues. This is consistent with the view of Obiyo and Lenee (2011).

Good corporate governance in the form of disclosure of financial information can be exercised to reduce the capital cost of the structure. In addition, good corporate governance helps to attract investment, both foreign and local, and helps reduce capital flight, and the fight against corruption, which by now everyone knows the extent of the obstruction represented by the growth. Unless investors can get the guarantees regarding the return on their investment, the funding will not flow to the businesses. Financial flows will not be achieved without the potential for growth of the structure. One of the main benefits of improved corporate governance is the increasing availability of funding and access to cheaper sources of funding, which increases the importance of governance in particular for developing countries (Yasser, Entebang, \& Abu Mansor, 2011). Finally, the application of the principles of governance as well as to provide an appropriate amount of security, safety and peace of mind for investors and shareholders to maintain their capital and access to an adequate return. And by ensuring sound management and the optimal use of available resources, as investors became citizens and foreigners attach great importance to the commitment of those companies (the seminal investment and contribute to) corporate governance mechanisms (Dry, 2003).

The audit committee's role in the implementation of corporate governance principles and in enhancing firm value is significant. According to the principles of corporate governance, audit committees should be independent and carry out their responsibilities with due professional care. In instances of financial manipulation, the audit committee is held accountable for it, which is why the transparency of financial information minimizes information asymmetry and enhances firm value (Bhagat \& Jefferis, 2002; Heenetigala \& Armstrong, 2011).

With the advent of the global financial crisis that negatively impacted global business entities, business entities have learned a great lesson from its negative outcome largely attributed to the inadequate strategies in executive committee. Hence, the executive committee has become an important factor in the context of how the company generates profits and maximizes shareholder value while making sure that economic stability is maintained in the country of operation. According to economists, the successive crises on the Muscat Securities Market (MSM) have led to the highlight of governance systems weaknesses and the public companies' ineffective executive committee. They called for the importance of creating committee's competent executive committee and the policy actions and investments diversification to create a strategy of executive committee in every company (Al-Rashidi \& Jamal, 2010). Although, the role of executive committee is not mentioned in the Omani code of the corporate governance but almost of listing companies have this committee. So that, this current study expected the executive committee has important role to help all listed companies to improve their performance.

This study aimed to focus on emerging market such Oman for many noteworthy reasons. Firstly, the corporate governance regulations were issued by the Capital Market Authority (CMA) in 2002, in reaction to the Omani corporation management criticisms following the $1997 \mathrm{crash}$. However, the corporate governance in Oman is still in its initial stages and the CMA is still attempting to educate the markets on the advantages reaped from effective corporate governance (World Bank, 2009). Additionally, reports claim that several regulations and institutions have just been laid down and are untested leading to the low awareness of effective corporate governance and the practices are still in their infancy stage. Secondly, Oman is the first country in the GCC to apply the code of corporate governance that it has implemented in 2002. Moreover, it is the only country in GCC that is not a member of OPEC. This reason is to give the boost to country's economic policies at any time. Consequently, oil prices in recent years reinforced Oman's budget, trade surpluses, and foreign reserves. Increased expenditures in 2011 associated with Oman`s Arab Spring (estimated at RO1 bn, or \$2.6 bn) offset increased oil revenues while high oil prices helped Oman avoid a budgetary deficit. Therefore, this study attempted to investigate the relationship between corporate governance dimension as mentioned above and their effects on the performance of public listed companies in Oman. Finally, there is a lack in existing the literature 
review about the relationship between corporate governance and firm performance in the gulf cooperation council. Therefore, this study is going to explore the association between some mechanisms of corporate governance and firm performance.

Regarding to above discussion, this study was an attempt to fill a gap in the literature by exploring the association between two important committees of corporate governance with accounting-based measurement (ROA). The data used in this study was based on the recent two years 2011 and 2012 like previous studies (Braun \& Sharma, 2007; Dey, 2008; Kim \& Yoon, 2008; Yasser, Entebang, \& Mansor, 2011). The next section is to provide a wide discussion of the relevant literature.

\section{Literature Review and Hypotheses Development}

\subsection{Audit Committee Characteristics and Firm Performance}

It is important to note that audit committee size, audit committee independence and audit committee meeting presumably could continue to serve as important elements of the corporate governance mechanism. However, the corporate governance regulators use them to ensure the management accountability and responsibility towards shareholders by ensuring that managers present true and fair view of the firms and avoid irregularities. Therefore, size, independence and meeting of the audit committee characteristics will serve as the blend of good corporate governance structure in creating firm's performance. Previous studies revealed mixed findings concerning the relationship between committee characteristics and firm performance as the next sub-section explains.

\subsubsection{Audit Committee Size and Firm Performance}

The size of the audit committee is considered as the first factor of audit committee characteristics. It is measured by the number of members serving on the audit committee of the firm (Bauer et al., 2009; Hsu \& Petchsakulwong, 2010; Nuryanah \& Islam, 2011; Obiyo \& Lenee, 2011).

In the $20^{\text {th }}$ century, following the biggest American corporate scandals of Enron and WorldCom, the Sarbanes-Oxley Act has become the magna carta of corporate disclosure and internal control, especially in relation to issuance of the duties of an audit committee. Recommendations are suggested by the Blue Ribbon Committee (BRC) in order to improve the effectiveness of a corporate audit committee (BRC, 1999). It recommends three important points that should be strengthened: independence, effectiveness and accountability. Moreover, the Cadbury Commission recommends that audit committees should be established, it is also recommends that audit committees should have a minimum size of three members and should consist of solely NEDs. In the same context, the Omani code of corporate governance mandates that the committee be comprised of at least three members who are all non-executive directors and majority of them have to be independent. The committee chairman should also be independent and at least one member is an expert in finance and accounting. Moreover, audit committees bridges the communication network between internal auditors and external auditors and it helps the board of directors in their activities such as nominating auditors and revising the audit scope, the audit results, internal financial information and publication of financial reports (Chanawongs, Poonpol, \& Poonpool, 2010). In the same context, the presence of audit committee plays an important monitoring and controlling role of management activities that results in increased performance of the firm (Mohd et al., 2009; $\mathrm{Xu}$ et al., 2005). In the same way, audit committee can reinforce the board in its implementation, monitoring and maintaining good corporate governance practices that benefit the firm and stakeholders (Saibaba \& Ansari, 2011).

After the importance of audit committee is globally verified and following the explanation of the role of audit committee in light of the Omani code, it can be finally stated that the audit committee helps a firm to improve its performance and it can attract the confidence of investors whether local or foreign. The financial report is very essential and sensitive matter for anyone looking for investing in a new environment. So, the audit committee has to approve satisfaction of the annual report. The current study offers an extensive discussion of the terms of several theories namely, agency theory and resource dependence theory. Arguing in favour of the agency theory and its proponents, when the number of members is bigger, the firm will display poor performance. Authors from around the world examined the relationship between audit committee size and firm performance whether in developed countries (Bozec, 2005) or in the developing countries (Al-Matari et al., 2012; Hsu \& Petchsakulwong, 2010; Mollah \& Talukdar, 2007). In the end, they found a negative association between them. For more details refer to the below Table 1. 
Table 1. Summary of previous studies that found a negative relationship between audit committee size and firm performance

\begin{tabular}{|c|c|c|c|c|}
\hline Authors and year & Location & Sample & Methods & DV \\
\hline Bozec (2005) & Canada & $\begin{array}{l}500 \text { large firms that were listed on } \\
\text { the Canadian Stock Exchange the } \\
\text { period was during } 1976 \text { to } 2000 \text {. }\end{array}$ & $\begin{array}{l}\text { Multiple } \\
\text { regressions. }\end{array}$ & $\begin{array}{lrr}\text { ROS, } & \text { ROA, } & \text { sales } \\
\text { efficiency, net income, } \\
\text { efficiency and } \\
\text { turnover }\end{array}$ \\
\hline \multicolumn{5}{|c|}{ In the developing countries } \\
\hline $\begin{array}{l}\text { Al-Matari et al. } \\
(2012)\end{array}$ & $\begin{array}{l}\text { Saudia } \\
\text { Arabia }\end{array}$ & $\begin{array}{l}135 \text { firms which listed on Saudi } \\
\text { Stock Market in } 2011 .\end{array}$ & $\begin{array}{l}\text { Multiple } \\
\text { regressions. }\end{array}$ & Tobin's Q \\
\hline $\begin{array}{l}\text { Hsu and } \\
\text { Petchsakulwong } \\
(2010)\end{array}$ & Thailand & $\begin{array}{l}\text { Public non-life insurance } \\
\text { companies in Thailand over the } \\
\text { period 2000-2007. }\end{array}$ & $\begin{array}{l}\text { Truncated } \\
\text { bootstrapped } \\
\text { regression. }\end{array}$ & DEA \\
\hline $\begin{array}{l}\text { MoIlah and } \\
\text { Talukdar (2007) }\end{array}$ & Bangladesh & $\begin{array}{l}55 \text { firms which were listed on } \\
\text { Dhaka Stock Exchange in } \\
\text { Bangladesh. The data were } \\
\text { obtained from } 2002 \text { to } 2004 \text {. }\end{array}$ & OLS regressions. & $\begin{array}{l}\text { ROA, ROE, log of market } \\
\text { and capitalization. }\end{array}$ \\
\hline
\end{tabular}

On the other hand, the resource dependence theory states that when the board of committee is bigger, a better performance is achieved. A small audit committee lacks the diversity offered by a large one in terms of skills and knowledge and this makes them ineffective. An audit committee with just the right number of members enables members to utilize their experience and expertise for the benefit of the stakeholders (Pfeffer, 1987; Pearce \& Zahra, 1992).

Supporting the resource dependence theory, there many researchers who a positive relationship between audit committee size and firm performance in developed countries as provide below in Table 2.

Table 2. Summary of previous studies that revealed a positive relationship between audit committee size and firm performance

\begin{tabular}{|c|c|c|c|c|}
\hline Authors and year & Location & Sample & Methods & DV \\
\hline Reddy et al. (2010) & $\begin{array}{l}\text { New } \\
\text { Zealand }\end{array}$ & 50 companies over the period $1999-2007$. & $\begin{array}{l}\text { OLS and } 2 \text { SLS } \\
\text { regression techniques. }\end{array}$ & $\begin{array}{l}\text { Tobin-Q, MP } \\
\text { and ROA }\end{array}$ \\
\hline Bauer et al. (2009) & US & $\begin{array}{l}113 \text { observations (firm-years) of real } \\
\text { estate investment trusts firms during } 2004 \\
\text { and } 2006\end{array}$ & OLS regression. & $\begin{array}{l}\text { Tobin-Q, ROA, } \\
\text { ROE and NPM }\end{array}$ \\
\hline $\begin{array}{l}\text { Premuroso and } \\
\text { Bhattacharya (2007) }\end{array}$ & US & 500 firms the period was through 2006 . & Multiple regressions. & $\begin{array}{l}\text { ROA, ROE and } \\
\text { NPM }\end{array}$ \\
\hline \multicolumn{5}{|l|}{ In the devoping country } \\
\hline $\begin{array}{l}\text { Al-Matari et al. } \\
(2012)\end{array}$ & Kuwait & 136 non-financial & Multiple regression & $\mathrm{ROA}$ \\
\hline Swamy (2011) & India & $\begin{array}{l}\text { Unlisted family owned firms in India, } 83 \\
\text { firms that his sample was from } 2008 \text { until } \\
2010 \text {. }\end{array}$ & $\begin{array}{l}\text { Panels Regression and } \\
\text { GLS. Primary data. }\end{array}$ & ROA and ROE \\
\hline $\begin{array}{l}\text { Obiyo and Lenee } \\
(2011)\end{array}$ & Nigeria & $\begin{array}{l}10 \text { firms of } 51 \text { firms of Banks, food, } \\
\text { construction and oil firms over } 2004 \text { and } \\
2008 \text {. }\end{array}$ & $\begin{array}{l}\text { The simple linear } \\
\text { regression. }\end{array}$ & $\begin{array}{l}\text { ROE, NPM and } \\
\text { DY }\end{array}$ \\
\hline
\end{tabular}

From a general perspective aside from the agency theory and the resource dependence theory, mixed findings are found. There are some studies that found no relationship (insignificant) between the audit committee and firm performance as provide in the below table; 
Table 3. Summary of previous studies that found no relationship between audit committee size and firm performance

\begin{tabular}{|c|c|c|c|c|}
\hline $\begin{array}{l}\text { Authors and } \\
\text { year }\end{array}$ & Location & Sample & Methods & DV \\
\hline Wei (2007) & China & $\begin{array}{l}276 \text { firms non-financial which were listed } \\
\text { on the Shanghai Stock Exchange and } \\
\text { Shenzhen Stock Exchange through } \\
\text { 1999-2002. }\end{array}$ & $\begin{array}{l}\text { Multiple } \\
\text { regressions. }\end{array}$ & $\begin{array}{l}\text { Market-to-book, } \\
\text { market-to-sales, ROA, gross } \\
\text { profit margin (GPM) }\end{array}$ \\
\hline \multicolumn{5}{|c|}{ In the developing countries } \\
\hline $\begin{array}{l}\text { Ghabayen } \\
(2012)\end{array}$ & $\begin{array}{l}\text { Saudia } \\
\text { Arabia }\end{array}$ & 102 non-financial firms in 2011 & $\begin{array}{l}\text { Multiple } \\
\text { regression }\end{array}$ & ROA \\
\hline $\begin{array}{l}\text { Nuryanah and } \\
\text { Islam (2011) }\end{array}$ & Indonesia & $\begin{array}{l}\text { From } 315 \text { listed companies, only } 46 \\
\text { companies were selected from financial } \\
\text { sectors during 2002-2004. }\end{array}$ & $\begin{array}{l}\text { Multiple } \\
\text { regressions }\end{array}$ & Tobin-Q \\
\hline Mohd (2011) & Malaysia & $\begin{array}{l}162 \text { non-financial firms through } 2006 \text { and } \\
2008 \text {. }\end{array}$ & $\begin{array}{l}\text { Multiple } \\
\text { regressions. }\end{array}$ & ROA \\
\hline
\end{tabular}

Based on the past literature regarding their relationships, the following hypothesis is formulated:

\section{H1: There is a relationship between audit committee size and ROA.}

\subsubsection{Audit Committee Independence and Firm Performance}

The second key of quality of the audit committee characteristics is its independence. Generally, the audit committee should have at least three directors with $2 / 3$ of the member's non-executive directors. The chairman is chosen from among the $2 / 3$ members and shall be appointed by the board. The audit committee independence is measured through the ratio of non-executive members on the committee (Abdullah et al., 2008; Kang \& Kim, 2011).

The non-executive members in the committee play a key role in guaranteeing that CG practices of auditing are adhered to effect financial report (Swamy, 2011). This is supported by Abdullah et al. (2008) who stated that firms with majority of inside directors and lacking an audit committee are more inclined to commit financial fraud compared to a controlled sample with a matching industry and size. Consequently, audit committees characterized by higher members of non-executive directors are viewed to be more independent compared to those characterized by more executive directors (Mohd et al., 2009).

Consequently, the Sarbanes-Oxley Act (2002) made it compulsory for audit committees of listed companies to comprise of independent directs and the current modifications to the Oman CG framework, which was introduced in 2008 mandated that the committee shall consist of at least three members who are non-executive with majority of them are independent. Also, the committee chairman should also be an independent director (Omani Code).

From both the agency theory and resource dependence theory, the autonomy is given to make the right decision without any restriction or condition, and to work in detecting errors and revealing them without any problems because the independent reviewers are not related to the company in any way. In addition, the relationship between audit committee independence is expected to be positive but there are only few studies that examined the relationship between audit committee independence and firm performance both in developed countries and developing countries as referred to the below Table 4 .

Table 4. Summary of previous studies that found a positive relationship between audit committee independence and firm performance

\begin{tabular}{|c|c|c|c|c|}
\hline $\begin{array}{l}\text { Authors and } \\
\text { year }\end{array}$ & Location & Sample & Methods & DV \\
\hline Dey (2008) & US & 371 firms through 2000 to 2001 & $\begin{array}{l}\text { Multiple } \\
\text { regressions. }\end{array}$ & $\begin{array}{l}\text { ROA and } \\
\text { Tobin-Q }\end{array}$ \\
\hline $\begin{array}{l}\text { Khanchel } \\
(2007)\end{array}$ & US & $\begin{array}{l}624 \text { US listed and non-financial firms for the period of } \\
1994-2003 .\end{array}$ & $\begin{array}{l}\text { Multiple } \\
\text { regressions } \\
\text { analyses. }\end{array}$ & Tobin-Q \\
\hline
\end{tabular}




\begin{tabular}{|c|c|c|c|c|}
\hline $\begin{array}{l}\text { Authors and } \\
\text { year }\end{array}$ & Location & Sample & Methods & DV \\
\hline \multicolumn{5}{|c|}{ In the developing countries } \\
\hline $\begin{array}{l}\text { Yasser et al. } \\
\text { (2011) }\end{array}$ & Pakistan & 30 Pakistan listed firms through 2008-2009. & $\begin{array}{l}\text { Multiple } \\
\text { regressions. }\end{array}$ & $\begin{array}{l}\text { ROE and } \\
\text { NPM }\end{array}$ \\
\hline $\begin{array}{l}\text { Nuryanah and } \\
\text { Islam (2011) }\end{array}$ & Indonesia & $\begin{array}{l}\text { From } 315 \text { listed companies, only } 46 \text { companies were } \\
\text { selected for this study. The sample data was selected } \\
\text { from financial sectors over } 2002-2004 \text {. }\end{array}$ & $\begin{array}{l}\text { Multiple } \\
\text { regressions }\end{array}$ & Tobin-Q \\
\hline
\end{tabular}

On the other hand, some researchers found a negative association between audit committee independence and firm performance in both developed countries and developing countries (Dar et al., 2011). For more information that refer to the below Table 5 .

Table 5. Summary of previous studies that found a negative relationship between audit committee independence and firm performance

\begin{tabular}{lllll}
\hline $\begin{array}{l}\text { Authors } \\
\text { and year }\end{array}$ & Location & Sample & Methods & DV \\
\hline $\begin{array}{l}\text { Dar et } \text { al. } \\
(2011)\end{array}$ & Pakistan & $\begin{array}{l}\text { This study selected 11 oil and gas firms listed on the Karachi stock } \\
\text { exchange and this study chooses non-profitability just over 2004-2010. }\end{array}$ & $\begin{array}{l}\text { Multiple } \\
\text { regressions }\end{array}$ & ROE \\
\hline
\end{tabular}

lastly, there are some researchers who found adverse results on prior outcome and revealed no relationship (insignificant) between audit committee independence and firm performance including as refer to the below Table 6.

Table 6. Summary of previous studies that found no relationship between audit committee independence and firm performance

\begin{tabular}{|c|c|c|c|c|}
\hline $\begin{array}{l}\text { Authors and } \\
\text { year }\end{array}$ & Location & Sample & Methods & DV \\
\hline $\begin{array}{l}\text { Al-Matari et } \\
\text { al. }(2012)\end{array}$ & $\begin{array}{l}\text { Saudia } \\
\text { Arabia }\end{array}$ & 62 firms which listed on Saudi Stock Market in 2011. & $\begin{array}{l}\text { Multiple } \\
\text { regressions. }\end{array}$ & $\begin{array}{l}\text { ROA and } \\
\text { Tobin's Q }\end{array}$ \\
\hline $\begin{array}{l}\text { Ghabayen } \\
(2012)\end{array}$ & $\begin{array}{l}\text { Saudia } \\
\text { Arabia }\end{array}$ & 102 non-financial firms in 2011 & $\begin{array}{l}\text { Multiple } \\
\text { regression }\end{array}$ & ROA \\
\hline $\begin{array}{l}\text { Al-Matari et } \\
\text { al. }(2012)\end{array}$ & $\begin{array}{l}\text { Saudia } \\
\text { Arabia }\end{array}$ & 135 firms which listed on Saudi Stock Market in 2011. & $\begin{array}{l}\text { Multiple } \\
\text { regressions. }\end{array}$ & Tobin's Q \\
\hline $\begin{array}{l}\text { Dar et al. } \\
(2011)\end{array}$ & Pakistan & $\begin{array}{l}\text { This study selected } 11 \text { oil and gas firms listed on the Karachi } \\
\text { stock exchange and this study chooses non-profitability just } \\
\text { over 2004-2010. }\end{array}$ & $\begin{array}{l}\text { Multiple } \\
\text { regressions }\end{array}$ & NPM \\
\hline
\end{tabular}

In light of the previous arguments and other supporting ones, the following hypothesis is proposed.

\section{H2: There is a positive relationship between audit committee independence and ROA.}

\subsubsection{Audit Committee Meeting and Firm Performance}

The audit committee meeting is the third vital factor of audit committee characteristics. Previous literature utilizes the meeting frequency to measure the activeness of audit committee (Hsu \& Petchsakulwong, 2010; Khanchel, 2007; Kyereboah-Coleman, 2007; Mohd et al., 2009).

The audit committee's effectiveness in conducting its overseeing role of financial reporting process and internal control calls for regular meetings (Vafeas, 2005). In addition, the meetings have to be at least done three or four times a year and the chairman must control and structure them (Hughes, 1999; McMullen \& Raghunandan, 1996).

In the same context, frequent and controlled meetings would be invaluable in helping audit committees to examine the accounting and internal control system, and informing top management concerning the committee's 
actions (McMullen \& Raghunandan, 1996). An executive director would explain the procedures and issues that may have cropped up (Hughes, 1999). Prior evidence is consistent with the guidelines provided by the Cadbury Committee (1992) in the U.K., the BRC (1999) in the U.S. The guidelines mandate audit committees to hold meetings not less than three times yearly. This is consistent with the Omani code of CG that mandates the committees holding of meetings at least four times yearly with a majority of independent directors. A properly planned meeting schedule guarantees the timeliness of the decision of the committee and the audit cycle and the financial statements issuance.

Moreover, the audit committee meeting is invaluable in improving firm performance as mentioned. Sharing a similar direction from the resource dependence theory, the board meeting helps the board to evaluate and pursue a board business from time to time and to solve any problem faced by employees (Pfeffer, 1987; Pearce \& Zahra, 1992).

In light of the resource dependence theory, the audit committee meeting has a positive relationship with firm performance. However, little research has been done on this association and they found a positive relationship between the audit committee meeting and firm performance both in the developed countries as follows.

Table 7. Summary of previous studies that found a positive association between audit committee meeting and firm performance

\begin{tabular}{|c|c|c|c|c|}
\hline Authors and year & Location & Sample & Methods & DV \\
\hline Khanchel (2007) & US & $\begin{array}{l}624 \text { US listed and non-financial firms for the period of } \\
1994-2003 \text {. }\end{array}$ & $\begin{array}{l}\text { Multiple } \\
\text { regressions } \\
\text { analyses }\end{array}$ & Tobin-Q \\
\hline \multicolumn{5}{|c|}{ In the developing countries } \\
\hline Kang and Kim (2011) & Korea & $\begin{array}{l}1104 \text { nonfinancial firms listing on the Korea stock } \\
\text { exchange over } 2005 \text { to } 2007 \text {. }\end{array}$ & $\begin{array}{l}\text { OLS and } \\
2 \text { SLS } \\
\text { regressions }\end{array}$ & Tobin-Q \\
\hline $\begin{array}{l}\text { Kyereboah-Coleman } \\
(2007)\end{array}$ & Africa & $\begin{array}{l}103 \text { listed firms drawn from Ghana, South Africa, Nigeria } \\
\text { and Kenya covering the five year period 1997-2001. }\end{array}$ & Regressions & Tobin-Q \\
\hline
\end{tabular}

From the perspective of the agency theory, Jensen (1993) revealed that boards should be inactive and its activity reflects a reaction to adverse performance. Also, Jackling and Johl (2009) and Lipton and Lorsch (1992) believed that the more frequent the meetings are, the more likely they will lead to superior performance of the firm. More specifically, frequent meetings every year indicates that the board is playing an operating role as opposed to an oversight role and it is generally believed that the role of the board is to govern management as opposed to manage the firm. In the context of Thailand, Hsu and Petchsakulwong (2010) examined the relationship between audit committee meeting and performance efficiency of public Thai non-life insurance companies for the period from 2000-2007. The insurance efficiency performance is utilized to calculate data envelopment such as technical, allocative, cost and revenue efficiency. This study used truncated bootstrapped regression and found a negative impact between audit committee meeting and performance efficiency.

Table 8 . Summary of prior studies that found a negative association between audit committee meeting and firm performance

\begin{tabular}{lllll}
\hline Authors and year & Location & Sample & Methods & DV \\
\hline $\begin{array}{l}\text { Hsu } \\
\text { Petchsakulwong (2010) }\end{array}$ & Thailand & $\begin{array}{l}\text { Public non-life insurance companies in Thailand } \\
\text { over the period 2000-2007. }\end{array}$ & $\begin{array}{l}\text { Truncated bootstrapped } \\
\text { regression }\end{array}$ & DEA \\
\hline
\end{tabular}

From a general perspective, no association (insignificant) was found between audit committee meeting and firm performance as evidenced by Al-Matari et al. (2012), Al-Matari et al. (2012), Mohd (2011) and Mohd et al. (2009). More details can be obtained from the below Table 9. 
Table 9. Summary of previous studies that found no association between audit committee meeting and firm performance

\begin{tabular}{|c|c|c|c|c|}
\hline Authors and year & Location & Sample & Methods & DV \\
\hline $\begin{array}{l}\text { Al-Matari et al. } \\
(2012)\end{array}$ & $\begin{array}{l}\text { Saudia } \\
\text { Arabia }\end{array}$ & $\begin{array}{l}135 \text { firms which listed on Saudi Stock } \\
\text { Market in } 2011 .\end{array}$ & $\begin{array}{l}\text { Multiple } \\
\text { regressions. }\end{array}$ & Tobin's Q \\
\hline $\begin{array}{l}\text { Al-Matari et al. } \\
(2012)\end{array}$ & $\begin{array}{l}\text { Saudia } \\
\text { Arabia }\end{array}$ & $\begin{array}{l}62 \text { firms which listed on Saudi Stock Market } \\
\text { in } 2011 .\end{array}$ & $\begin{array}{l}\text { Multiple } \\
\text { regressions. }\end{array}$ & $\begin{array}{l}\text { ROA } \\
\text { Tobin's Q }\end{array}$ \\
\hline Mohd (2011) & Malaysia & $\begin{array}{l}162 \text { non-financial firms through } 2006 \text { and } \\
2008 \text {. }\end{array}$ & $\begin{array}{l}\text { Multiple } \\
\text { regressions. }\end{array}$ & ROA \\
\hline
\end{tabular}

Based on the conflict evident between the theories and past evidence, the results are still conclusive. Hence, the following hypothesis formulated below is to be further examined:

\section{H3: There is a relationship between audit committee meeting and ROA.}

\subsection{The Executive Committee Characteristics and Firm Performance}

The executive committee is a sub-committee in the board like purchase committee, remuneration committee and others. The executive committee unfortunately like other committees is not considered at par with the audit committee in the code of corporate governance.

The executive committee exercises the powers and functions vested in it by the board of directors with respect to certain specific issues relevant to the institution and its bidding policies and other urgent matters referred to them by the management of the institution and in accordance with the provisions of the list of the powers, authorities and the procurement system and acquisition of assets accredited institution. The executive committee has been configured to facilitate decision-making when there are difficulties for the meeting of the governing council of the whole. Executive committee is focused on strategic issues, responsible for all matters related to the budget and procurement. The commission has the powers and the appropriate authorities to guide and direct management to ensure that the company's operations are managed readily and conveniently.

Although executive committee characteristic is an essential element of board structure, there is no study that investigated its relation with firm performance. Hence, the present study provides insights on the importance of the executive committee. With the global financial crisis of recent times that collapsed many of the global commercial entities, a big lesson has been learned by business entities and they have employed appropriate strategies for executive management. Therefore, executive management has become one of the most important elements in the context of what the company is doing to generate revenue and maximize shareholder value while maintaining the economic stability of the country in which they operate (Al-Rashidi \& Jamal, 2010).

In addition, the global code, Gulf code and Oman code failed to highlight the significance of this committee although it has important role to assure investors to give them a clear picture to invest without concern about risk in the future and provide the board with a report concerning risk in any operations whether in current situation or in the future. It is also important to note that the Omani code of corporate governance established in 2002 has not been updated according to the development taking place in the global code. Therefore, the capital market authority must update Omani code in order to keep pace with the evolution in the world to encourage both local and foreign investors to come and invest in the country. Regarding to the importance of this committee, this current study is going to test the relationship between the executive committee characteristics and firm performance.

\subsubsection{The Executive Committee Size and Firm Performance}

The literature dedicated to executive committee characteristics and firm performance is very limited no study has been done at the present study's caliber. However, the current study discusses studies that examined the relationship between the board size and firm performance. The executive committee size is measured by the number of members in the executive committee. Finally, boards with more members are more diverse with significant connections to the external environment for critical resources and novel ideas for effective choices relating to corporate policies that will improve board efficiency (Goodstein et al., 1994; Nanka-Bruce, 2011). Due to the lack of literature related to the relationship between executive committee size and firm performance and in the light of the agency theory and resource dependence theory, the following hypothesis is formulated:

H4: There is a relationship between the executive committee size and ROA. 


\subsubsection{The Executive Committee Independence and Firm Performance}

The second factor of the executive committee characteristics is the executive committee independence. The executive committee independence is measured by the number of independent members in the executive committee. This variable shows lack of empirical evidence and therefore the current study attempts to achieve its target to examine this variable with firm performance. In this section, some theoretical evidence is reviewed concerning executive committee independence.

Moreover, the independent board members are more persistent in their monitoring of the firms decisions as they hold the responsibility of guaranteeing superior financial performance (Johnson et al., 1993; Stanwick \& Stanwick, 2010). Similarly, independent directors on the board are independent and are not controlled or influenced by major shareholders, management or other parties. Thus, they are more inclined to look into management and monitor them for the purpose of preventing fraud as they have no ties, economic or psychological, to management (Hsu \& Petchsakulwong, 2010). Under agency theory, Berle and Means (1932) and Fama and Jensen (1983) explained that board outsiders could strengthen the firm's value by lending experience and monitoring services. Along the same line of reasoning, outside directors are supposed to be guardians of the shareholders' interests via monitoring and their expertise is developed from prior experience (Mace, 1986).

In the same context, under the resource dependence theory, the integration of the independent members and dependent ones on the board provide multiple resources which helps to improve performance of firms. And independent members can use their experience and knowledge to make a timely right decision (Pearce \& Zahra, 1992; Pfeffer, 1987). Therefore, this study was investigates this relation and expects that executive committee independence improves firm performance. Based on previous discussion and theoretical evidence, the following hypothesis is proposed:

\section{H5: There is a positive relationship between the executive committee independence and ROA.}

\subsubsection{The Executive Committee Meeting and Firm Performance}

The executive committee meeting is essentially the third factor of the executive committee characteristics which the effectiveness of a board also depends on. Board meeting frequency can improve the efficiency of the firm performance, since the board has more opportunities to monitor and review management's performance (Hsu \& Petchsakulwong, 2010). The executive committee is measured by the frequency of its meeting in a year.

Jackling and Johl (2009) and Lipton and Lorsch (1992) suggested that the greater the frequency of meetings, the more superior the result is likely to be. In a similar argument, Conger et al. (1998) and Kyereboah-Coleman (2007) suggested that board meeting time is an important resource for improving the effectiveness of a corporate board. Additionally, the implication is that when boards of directors meet frequently, they are likely to enhance firm performance and thus perform their duties in accordance with shareholders' interests (Kyereboah-Coleman, 2007). As a consequence, boards should be prepared to increase their meeting frequency if the situation calls for higher supervision and control (Khanchel, 2007; Shivdasani \& Zenner, 2002).

Consistent with the above, the resource dependency theory relates corporate governance and performance and links them with the intensity of board activity, measured through the board meeting frequency. The resource postulates that the board meeting helps the board to evaluate and pursue a board business from time to time and to solve any problem faced by employees. Hence, when the board meeting frequency increases, the performance of the firm is expected to be more enhanced. On the other hand, from the perspective of the agency theory, Jensen (1993) claimed that boards should be inactive as their activity reflects their response to adverse performance. Therefore, the following hypothesis is postulated:

\section{H6: There is a relationship between the frequency of the executive committee meeting and ROA.}

\section{Research Method and the Study Model}

The Muscat Securities Market (MSM) lists 169 firms in which all are categorized into groups according to their similarities. The study population consists of the category of non-financial firms listed in this Stock Exchange (http://www.msm.gov.om/). According to the above body, there are 81 non-financial companies included on the main board and secondary board as of 20th September 2012. Therefore, the information provided for the 81 per year non-financial firms will be retrieved and used for the hypothesis testing so that totally data used for two years equal 162 firms. The firm performance was measured by ROA because the size of the firm impacts firm performance and it is commonly utilized as a control variable in empirical literature concerning corporate governance (e.g. Andres et al., 2005; Ghosh, 2006). Firm size impact upon corporate governance is evident in the findings that show large companies to be less effective compared to smaller companies because although they 
meet government bureaucracy, they have more ambiguity and higher agency issues (Patro et al., 2003).

The 6 internal corporate governance variables namely, the audit committee size (ACSIZE), the audit committee independence (ACINDE), the audit committee meeting (ACMEETIN), the executive committee size (ECSIZE), the executive committee independence (ECINDE), the executive committee meeting (ECMEETIN) and two control variables (LEGALCO), firm size (FIRMSIZE), leverage (LEVERAG) were studied. Table 10 offers variables measurement summary.

The relationship between the audit committee characteristics (size, independence and meeting), executive committee characteristics (size, independence and meeting) and two control variables (LEGALCO) were tested by using the following model:

$\mathbf{R O A}=\boldsymbol{\alpha} \mathbf{0}+\boldsymbol{\beta} 1 * \mathrm{ACSIZE}+\boldsymbol{\beta} 2 * \mathrm{ACINDE}+\boldsymbol{\beta} 3 * \mathrm{ACMEETIN}+\boldsymbol{\beta} 4 * \mathrm{RCSIZE}+\boldsymbol{\beta} 5 * \mathrm{RCINDE}+\boldsymbol{\beta} 6 * \mathrm{RCMEETIN}+\boldsymbol{\beta} 7 *$ FIRMSIZE $+\boldsymbol{\beta} \boldsymbol{8}^{*}$ LEVERAG $+\boldsymbol{\varepsilon}$

Table 10. Summary of variables measurement

\begin{tabular}{|c|c|c|c|}
\hline $\begin{array}{l}\text { N0 } \\
\text { Dep }\end{array}$ & \multicolumn{2}{|c|}{ Dependent Variables (DV) } & Operationalization \\
\hline 1 & Return On Assets ratio (\%) & ROA & Earnings before tax divided by total assets of the company. \\
\hline \multicolumn{4}{|c|}{ Independent Variables (IV) } \\
\hline 2 & $\begin{array}{l}\text { Audit Committee } \quad \text { Size } \\
\text { (number) }\end{array}$ & ACSIZE & Number of members serving on the audit committee. \\
\hline 3 & $\begin{array}{l}\text { Audit Committee } \\
\text { Independence }(\%)\end{array}$ & ACINDE & Number of non-executive members serving on the audit committee. \\
\hline 4 & $\begin{array}{l}\text { Audit Committee Meeting } \\
\text { (number) }\end{array}$ & ACMEETIN & $\begin{array}{l}\text { The frequency number of meetings during a year for the audit } \\
\text { committee. }\end{array}$ \\
\hline 5 & $\begin{array}{l}\text { The Executive Committee } \\
\text { Size (number) }\end{array}$ & ECSIZE & Total number of members in the executive committee. \\
\hline 6 & $\begin{array}{l}\text { The Executive Committee } \\
\text { Independence }(\%)\end{array}$ & ECINDE & $\begin{array}{l}\text { The number of independent non-executive directors on the committee } \\
\text { relative to the total number of the executive committee. }\end{array}$ \\
\hline 7 & $\begin{array}{l}\text { The Executive Committee } \\
\text { Meeting (number) }\end{array}$ & ECMEETIN & $\begin{array}{l}\text { The frequency number of meetings during a year for the executive } \\
\text { committee. }\end{array}$ \\
\hline \multicolumn{4}{|c|}{ Control Variables (CV) } \\
\hline 8 & Firm Size (number) & FIRMSIZE & The natural log of total assets. \\
\hline 9 & Leverage $(\%)$ & LEVERAG & The ratio of total liabilities to total assets. \\
\hline
\end{tabular}

\section{Data Analysis and Results}

The gathered data is analyzed through IBM SPSS for data description and hypothesis testing.

\subsection{Descriptive Statistic}

The descriptive statistics result of the continuous variables is presented in Table 11. This includes mean, standard deviation, minimum and maximum, which are obtained through SPSS, Version 21.

Table 11. Descriptive statistics of continuous variables

\begin{tabular}{llllll}
\hline Variables & Unit & Mean & Std. Deviation & Min & Max \\
\hline Audit Committee Size (ACSIZE) & Number & 3.52 & 0.72 & 3.00 & 7.00 \\
Audit Committee Independence (ACINDE) & Ratio & 0.93 & 0.19 & 0.00 & 1.00 \\
Audit Committee Meeting (ACMEETIN) & Number & 4.74 & 1.28 & 0.00 & 9.00 \\
Executive Committee Size (ECSIZE) & Number & 2.14 & 1.88 & 0.00 & 6.00 \\
Executive Committee Independence (ECINDE) & Ratio & 0.54 & 0.46 & 0.00 & 1.00 \\
Executive Committee Meeting (ECMEETIN) & Number & 2.18 & 2.37 & 0.00 & 13.00 \\
FIRM SIZE (FIRMSIZE) & OR & 62979251.03 & 125657047.90 & 605320.00 & 685377000.00 \\
LEVERAGE (LEVERAG) & Ratio & 0.49 & 0.28 & 0.02 & 1.72 \\
Return On Assets (ROA) & Ratio & 0.06 & 0.10 & -0.34 & 0.32 \\
\hline
\end{tabular}




\subsection{Correlation Analysis}

The summary of the correlation results are presented in Table 12. The results reveal that the entire correlations are lower than 0.80, which satisfies Gujarati and Porter's (2009) statement that the correlation matrix should not be more than 0.80 to ensure the absence of multicollinearity issue. Moreover, the variables' tolerance values are listed in Table 13 and according to the table, the values range between 0.192 and 0.962 with VIF values ranging between 1.040 and 5.201. All the tolerance values are greater than 0.1 and all VIF values are below 10 as suggested by Hair et al. (2010). In other words, the variables' tolerance values and VIF values satisfy the recommended range. Therefore, it can be concluded that the issue of multicollinearity is non-existent.

Table 12. Results of Pearson correlation analysis

\begin{tabular}{|c|c|c|c|c|c|c|c|c|c|}
\hline & 1 & 2 & 3 & 4 & 5 & 6 & 7 & 8 & 9 \\
\hline \multicolumn{10}{|l|}{ 1) ACSIZE } \\
\hline 2) ACINDE & $.137^{*}$ & & & & & & & & \\
\hline 3) ACMEETIN & .127 & .112 & & & & & & & \\
\hline 4) RCSIZE & $.235 * * *$ & .099 & $.242 * * *$ & & & & & & \\
\hline 5) RCINDE & $.182 * *$ & $.224 * * *$ & .122 & $.869 * * *$ & & & & & \\
\hline 6) RCMEETIN & $.187 * *$ & .110 & $.254 * *$ & $.725 * * *$ & $.719^{* * *}$ & & & & \\
\hline 7) FIRMSIZE & $.194 * *$ & .020 & $.217 * * *$ & .101 & .037 & .100 & & & \\
\hline 8) LEVERAG & -.059 & -.015 & -.028 & $-.145^{*}$ & -.076 & -.122 & -.062 & & \\
\hline 9) $\mathrm{ROA}$ & .076 & -.001 & .099 & .123 & .083 & $.145^{*}$ & $.257 * * *$ & $-.451 * * *$ & \\
\hline
\end{tabular}

Notes: $* * *$ Correlation is significant at the 0.01 level (2- tailed).

** Correlation is significant at the 0.05 level (2- tailed).

* Correlation is significant at the 0.1 level (2- tailed).

\subsection{Multiple Linear Regression Analysis}

One of the most commonly used statistical methods in many applications of science disciplines is the regression analysis (Hair et al., 2010). According to DeCoster (2004), a regression is a statistical method allowing the researcher's prediction of the value of one variable from one or more other variables. He stated that when the regression analysis is performed, a regression equation predicting the dependent variable's value through the values of the independent variables arises. Therefore, in this study, linear regression analysis was employed to determine the direct relationship between independent variable and dependent variable and to determine the relationship direction. According to Pallant (2011), linear regression can be employed for the prediction of the value of single continuous dependent variable from a single continuous independent variable.

Table 13. Multicollinearity test

\begin{tabular}{lll}
\hline Variables & Tolerance Value & VIF \\
\hline Audit Committee Size (ACSIZE) & .898 & 1.114 \\
Audit Committee Independence (ACINDE) & .874 & 1.144 \\
Audit Committee Meeting (ACMEETIN) & .833 & 1.201 \\
Executive Committee Size (ECSIZE) & .195 & 5.137 \\
Executive Committee Independence (ECINDE) & .192 & 5.201 \\
Executive Committee Meeting (ECMEETIN) & .425 & 2.354 \\
FIRM SIZE (FIRMSIZE) & .918 & 1.089 \\
LEVERAGE (LEVERAG) & .962 & 1.040 \\
\hline
\end{tabular}

\subsubsection{Regression Results of Model (Based on Accounting-based Measure ROA)}

The regression results of ROA are presented in Table 14 with the $\mathrm{R}^{2}$ value $=0.263$, indicating that the model explains $26 \%$ of the variance in the performance of the firm as measured by ROA. This result is viewed as a 
respectable one. The adjusted $\mathrm{R}^{2}$ coefficient of determination shows that $0.224 \%$ of the variation in the dependent variable is explained by the independent variable's variations. This indicates the firm performance variation as gauged by ROA, was statistically explained by the equation. Table 14 shows significance of the model with significant $F$ value of $(F=6.810, p<0.01)$. Finally, Durbin-Watson (DW) test is utilized as a statistical test for the detection of autocorrelation. In this regard, Reinard (2006) and Kazmier (1996) stated that the values of the test statistics can range from 0 to 4.0. Generally, if the value of the statistic is below 1.4, it indicates the existence of a strong positive series of correlation, while a value greater than 2.6 indicates the existence of a strong negative series correlation (Kazmier, 1996). As a rule of thumb, Durbin-Watson should be within the acceptable range of 1.5 to 2.5 . With consistent to Table 14, Durbin-Watson (DW) was found to be 1.881 indicating no autocorrelation issue.

This study found a surprising insignificant association between audit committee size and ROA, as apparent in Table 14 There is no association between audit committee size and RAO. Thus, hypothesis H1 is not supported. This result is consistent with previous studies of Wei (2007) in China, Ghabayen (2012), Mohd (2011) and Nuryanah and Islam (2011) in developing countries. A potential reason for insignificant finding of audit committee size and ROA is that audit committees in Oman is not considered as important compared to as in other countries. This result matches the insignificant result on audit committee size indicating that the role of some specific board practices aspects in developed countries of firm performance is absent in the case of Oman. Moreover, this study found a surprising insignificant relationship between audit committee independence and ROA so that $\mathrm{H} 2$ is not supported. This result also does not support the recommendation of Sarbanes-Oxley Act (2002), Cadbury Committee (1992) in the U.K and the Omani corporate governance code (2002). This result is consistent with previous studies that found no association between audit committee independence and ROA in developing countries like Al-Matari et al. (2012), Al-Matari et al. (2012), Dar et al. (2011) and Ghabayen (2012). One possible reason for insignificant result of audit committee independence is that it may be significant to appoint individuals with technical expertise and experience in order to guarantee value creation. Therefore, the Omani capital market authority must be a leading example to all listed companies to appoint persons with high qualifications in order to improve long-term company plans.

This study hypothesized that there is a relationship between audit committee meeting and ROA. However, the result as apparent in Table 14, found no significant association between them. Therefore, hypothesis 3 is not supported. This result is similar with previous studies that are conducted by Al-Matari et al. (2012), Al-Matari et al. (2012), and Mohd (2011) who found insignificant relationship between audit committee meeting and ROA. One possible explanation for this insignificant is that the frequency of audit committee meetings and ROA is that board meetings are not always useful as limited time NEDs spend together is not spent on exchanging meaningful ideas among themselves and with management. This is generally acknowledged to naturally stem from the fact that setting the agency for these meetings is conducted by chief executive officers. Additionally, this study predicted that the executive committee size has a relationship with ROA. But the result is in conflict with the expectation as apparent in Table 14. This relationship was found to be insignificant. Therefore, the hypothesis $\mathrm{H} 4$ is not supported. The presence of the insignificant result between the size of executive committee and ROA may be due to the fact that executive committees are not considered as important as other committees in Oman. This result indicates that the role of some specific board of director's practices of firm performance does not exist in Oman. Executive committee is not taken into consideration along with its role and the value behind it in Oman.

This study found insignificant association between executive committee independence and ROA as apparent in Table 14. Hence, H5 is not supported. A possible reason behind this insignificant finding is due to the mere presence of executive committee independence on the board which may not be sufficient for executive committee to carry out its monitoring roles in order to better operate firm. This should also be coupled with majority of expert-independent members of the committee to ensure firm value. Besides, this study, as apparent in Table 14, found insignificant association between executive committee meeting and ROA. Therefore, H6 is not supported. The insignificant relationship between the frequency of executive committee meetings and ROA may be due to the inefficient board meetings as the limited time NEDs spend in meetings is not spent in exchanging useful ideas among themselves and management. This stems from the fact that meetings are frequently headed by the chief executive officers.

Based on the regression results the model equation is ROA $=-0.113+0.033 *$ FIRM SIZE (FIRMSIZE)-0.154* LEVERAGE (LEVERAG). 
Table 14. Regression results of model (Dependent $=$ ROA)

\begin{tabular}{llcc}
\hline Variables & Standardized Coefficients & t-value & Sig. \\
\hline Audit Committee Size (ACSIZE) & Beta & -.013 & .989 \\
Audit Committee Independence (ACINDE) & -.001 & -.342 & .733 \\
Audit Committee Meeting (ACMEETIN) & -.025 & .390 & .697 \\
Executive Committee Size (ECSIZE) & .030 & -.328 & .744 \\
Executive Committee Independence (ECINDE) & -.052 & .186 & .852 \\
Executive Committee Meeting (ECMEETIN) & .030 & .772 & .441 \\
FIRM SIZE (FIRMSIZE) & .082 & 3.046 & .003 \\
LEVERAGE (LEVERAG) & .221 & -6.104 & .000 \\
R2 & -.432 & .263 \\
Adjusted R2 & & .224 \\
F-value & & & 6.810 \\
F-Significant & & & 0.000 \\
Durbin Watson statistics & & & 1.881 \\
\hline
\end{tabular}

\section{Conclusion}

This study studied the effect of the audit committee characteristics namely size, independence and meeting and executive committee characteristics (namely size, independence and meeting) on the performance (ROA). Data used comprised of non-financial firms listed in the Muscat Security Market (MSM) during 2011and 2012. As previously mentioned, the study is motivated by the existence of the gap in literature and the lack of evidence concerning the topic in developing countries like Oman. The present study adds to the understanding of corporate governance characteristics that impact the performance of the firm, particularly with Oman's distinct culture and environment.

Although this study was consistent to prior researches studying the integration between board characteristics and audit committee characteristics to firm performance, it is unique to itself in that it added board committee in this integration because it has an important role in encouraging all listed companies to improve their performance in order to establish a strong infrastructure of investments. Therefore, this study examined this committee in light of performance.

The applicability of the resource dependence theory is more suited to majority of businesses in Oman; as the diversity of the board enables performance improvement through diverse experiences, qualifications and nationalities of the members. This study is consistent with the contention that the agency theory is not suitable to be applied in Omani environment. Despite the practice of Omani companies of corporate governance, improvements are still called for in Oman for their reinforcement.

\section{Limitations and Suggestions for Future Research}

Firstly, although this study examined the effect of audit committee and executive committee on firm performance, the results need more examination so it suggests future research to investigate this relation again. Secondly, this study examined the relationship between audit committee and executive committee only and firm performance. Therefore, this study suggests future researchers to study this relation with board director's characteristics and with other committee on the board in order to enhance the performance of the company. Third, the present study considered ROA as proxy of performance and hence further studies should employ other proxies such as the Tobin's Q or ROE for firm performance.

Fourthly, one of the objectives of this study was to provide a clear picture about regulations and structure of corporate governance in Oman. However, future studies could focus on emerging markets in the gulf countries and conduct a comparison among all Gulf countries. More attention, as explained in previous chapters, is needed due to the lack of studies in developing countries in general and in the Gulf countries in particular. Therefore, future researchers should intensify their efforts in many studies in the Gulf States as it is of utmost importance. Fifthly, this study is limited to two years data so that it cannot be generalized to all. Therefore, this study suggests future researches to extend this sample for many years in order contribute to study validity. Sixthly, owing to the wide relationship between corporate governance and firm performance in the existing literature, 
future research should examine moderating and mediating effects of some variables, such as board diversity, on this relationship.

\section{References}

Abdullah, M. S., Shah, S. Z. A., \& Hassan, A. (2008). Impact of Corporate Governance on Financial Performance of Firms: Evidence from Pakistan. The Business Review, 11, 282-290.

Al-Manaseer, M. F. A., Al-Hindawi, R. M., Al-Dahiyat, M. A., \& Sartawi, I. I. (2012). The Impact of Corporate Governance on the Performance of Jordanian Banks. European Journal of Scientific Research, 67(3), 349-359.

Al-Matari, E. M., Al-Swidi, A. K., Faudziah, H. B., \& Al-Matari, Y. A. (2012). The Impact of board characteristics on Firm Performance: Evidence from Nonfinancial Listed Companies in Kuwaiti Stock Exchange. International Journal of Accounting and Financial Reporting, 2(2), 310-332. http://dx.doi.org/10.5296/ijafr.v2i2.2384

Al-Matari, Y. A., Al-Swidi, A. K., \& Fadzil, F. H. B. (2012). Audit committee effectiveness and performance of Saudi Arabia listed companies. Wulfenia Journal, 19(8), 169-188.

Al-Matari, Y. A., Al-Swidi, A. K., Fadzil, F. H. B., \& Al-Matari, E. M. (2012). Board of directors, audit committee characteristics and performance of Saudi Arabia listed companies. International Review of Management and Marketing, 2(4), 241-251.

Al-Rashid, F., \& Jamal, A. (2010). The importance of corporate governance in the Arab countries. For corporate governance conference in Kuwait.

Andres, P., Azofra, V., \& Lopez, F. (2005). Corporate boards in OECD countries: Size, composition, functioning and effectiveness. Corporate Governance International Review, 13(2), 197-210. http://dx.doi.org/10.1111/j.1467-8683.2005.00418.x

Bauer, R., Eichholtz, P., \& Kok, N. (2009). Real estate, corporate governance and performance: The Reit Effect. Financial Management, $X X(\mathrm{XX}), 1-29$.

Berle, A., \& Means, G. (1932). The Modern Corporation and Private Property. New York, NY: Macmillan.

Bhagat, S., \& Jefferis, R. (2002). The econometrics of corporate governance studies. MIT Press, Cambridge.

Bøhren, Ø., \& Strøm, R. Ø. (2010). Governance and Politics: Regulating Independence and Diversity in the Board Room. Journal of Business Finance \& Accounting, 37(9), 1281-1308. http://dx.doi.org/10.1111/j.1468-5957.2010.02222.x

Bozec, R. (2005). Boards of directors, Market discipline and Firm Performance. Journal of Business Accounting, 32(9\&10), 1921-1960. http://dx.doi.org/10.1111/j.0306-686X.2005.00652.x

Brown, L. D., \& Caylor, M. L. (2006). Corporate governance and firm valuation. Journal of Accounting and Public Policy, 25(2), 409-434. http://dx.doi.org/10.1016/j.jaccpubpol.2006.05.005

Chanawongse, K., Poonpol, P., \& Poonpool, N. (2011). The effect of auditor professional on audit quality: An empirical study of certified public accountants (Cpas) In Thailand. International Journal of Business Research, 11(3), 113-127.

Conger, J., Lawler, E., \& Finegold, D. (1998). Corporate boards: Strategies for adding value at the top. San Francisco, CA: Jossey-Bass.

Dar, L. A., Naseem, M. A., Rehman, R. U., \& Niazi, G. S. (2011). Corporate Governance and Firm Performance a Case Study of Pakistan Oil and Gas Companies Listed in Karachi Stock Exchange. Global Journal of Management and Business Research, 11(8), 1-10.

DeCoster, J. (2004). Data Analysis in SPSS.

Dey, A. (2008). Corporate governance and agency conflicts. Journal of Accounting Research, 46(5), 1143-1181.

Dry, E. K. (2003). Corporate governance in the Sultanate of Oman, 1(3), 45-82.

Fama, E. F., \& Jensen, M. C. (1983). Separation of ownership and control. Journal of Law and Economics, 26, 301-325. http://dx.doi.org/10.1086/467037

Fama, E., \& Jensen, M. (1983). Agency problems and residual claims. The Journal of Law and Economics, 26(2), 327-349. http://dx.doi.org/10.1086/467038

Ghabayen, M. (2012). Board characteristics and firm performance: Case of Saudi Arabia. International Journal of Accounting and Financial Reporting, 2(2), 168-200. http://dx.doi.org/10.5296/ijafr.v2i2.2145

Ghosh, S. (2006). Do board characteristics affect corporate performance? Firm-level evidence for India. Appl. 
Econ. Lett., 13, 435-443. http://dx.doi.org/10.1080/13504850500398617

Goodstein, J., Gautam, K., \& Boeker, W. (1994). The effects of board size and diversity on strategic change. Strategic Management Journal, 15, 241-250. http://dx.doi.org/10.1002/smj.4250150305

Gujarati, D., \& Porter, D. (2009). Basic Econometrics (5th ed.). New York: McGraw-Hill.

Hair, J. F., Anderson, R. E., Tatham, R. L., \& Black, W. C. (2010). Multivariate data analysis (2nd ed.). New York: Prentice-Hall, Upper Saddle River, NJ.

Heenetigala, K., \& Armstrong, A. (2011). The impact of corporate governance on firm performance in an unstable economic and political environment: Evidence from Sri Lanka. Conference on financial markets and corporate governance, 13, 1-17.

Hsu, W., \& Petchsakulwong, P. (2010). The impact of corporate governance on the efficiency performance of the Thai non-life insurance industry. The Geneva Papers on Risk and Insurance Issues and Practice, 35(1), S28-S49. http://dx.doi.org/10.1057/gpp.2010.30

Hughes. (1999). The rise of the audit committee in UK quoted companies: A curious phenomenon Accounting. Business and Financial History, 6(2), 121-140.

Jackling, B., \& Johl, S. (2009). Board structure and firm performance: Evidence from India's top companies. Corporate Governance: An International Review, 17(4), 492-509. http://dx.doi.org/10.1111/j.1467-8683. 2009.00760.x

Jensen, M. (1993). The modern industrial revolution, exit and the failure of internal control systems. Journal of Finance, 48, 831-880. http://dx.doi.org/10.1111/j.1540-6261.1993.tb04022.x

Johnson, R. A., Hoskisson, R. E., \& Hitt, M. A. (1993). Board of director involvement in restructuring: The effects of board versus managerial controls and characteristics. Strategic Management Journal, 14, 33-50. http://dx.doi.org/10.1002/smj.4250140905

Kang, S., \& Kim, Y. (2011). Does earnings management amplify the association between corporate governance and firm performance? Evidence from Korea. International Business and Economies Research Journal, $10(2), 53-67$.

Kazmier, L. (1996). Schaum's Outline of Theory and Problems of Business Statistics. McGraw-Hill, 1996-Business and Economics-410 pages.

Khanchel, I. (2007). Corporate governance: Measurement and determinant analysis. Managerial Auditing Journal, 22(8), 740-760. http://dx.doi.org/10.1108/02686900710819625

Kim, H. J., \& Yoon, S. S. (2007). Corporate governance and firm performance in Korea. Malaysian Accounting Review, 6(2), 1-18.

Kyereboah-Colema, A. (2007). Corporate governance and firm performance in Africa: A dynamic panel data analysis. Studies in Economics and Econometrics, 32(2), 1-24.

Lipton, M., \& Lorsch, J. (1992). Modest proposal for improved corporate governance. Business Lawyer, 12(3), 48-59.

Mace, M. (1986). Directors: Myth and Reality. Boston: Harvard Business School Press.

McMullen, D. A., \& Raghunandan, K. (1996). Enhancing audit committee effectiveness. Journal of Accountancy, $182(2), 79-81$.

Mohd, A. M. N. (2011). The effect of implementation of Malaysia code of corporate governance (MCCG) 2007 on corporate governance attributes and financial performance. Ph.D DPA Dissertation, University Utara Malaysia.

Mohd, M. R., Takiah, M. I., \& Norman, M. S. (2009). Audit committee characteristics in financially distressed and non-distressed companies. Managerial Auditing Journal, 24(7), 624-638. http://dx.doi.org/10.1108/02686900910975350

Mollah, A. S., \& Talukdar, M. B. U. (2007). Ownership structure, corporate governance, and firm's performance in emerging markets: Evidence from Bangladesh. The International Journal of Finance, 19(1), 4315-4333.

Mokhtar, S. M., Sori, Z. M., Hamid, M. A., Abidin, Z. Z., Nasir, A. M., Yaacob, A. S., .., Muhamad, S. (2009). Corporate governance practices and firms performance: The Malaysian case. Journal of Money, Investment and Banking, 11, 45-59.

Muscat Securities Market, MSM Statistics. (2001). Retrieved December 30, 2001, from http://www.msm.gov.com 
Nanka-Bruce, D. (2011). Corporate governance mechanisms and firm efficiency. International Journal of Business and Management, 6(5), 28-41. http://dx.doi.org/10.5539/ijbm.v6n5p28

Nuryanah, S., \& Islam, S. M. N. (2011). Corporate governance and performance: Evidence from an emerging market. Malaysian Accounting Review, 10(1), 17-42.

Obiyo, O. C., \& Lenee, L. T. (2011). Corporate governance and firm performance in Nigeria. IJEMR, 1(4), 1-12.

OECD. (2003). Corporate governance in Asia: A comparative perspective. Conference Proceedings (Seoul, Korea).

OECD. (2004). Principles of Corporate Governance.

Pallant, J. F. (2011). SPSS Survival Manual: A step by step guide to data analysis using SPSS (4th ed.). Crow's Nest, NSW: Allen \& Unwin.

Patro, S., Lehn, K., \& Zhao, M. (2003). Determinants of the size and structure of corporate boards: 1935-2000. Financial Management, 38, 1-57.

Pearce, J. H., \& Zahra, S. A. (1992). Board composition from a strategic contingency perspective. Journal of Management Studies, 29(2), 411-438. http://dx.doi.org/10.1111/j.1467-6486.1992.tb00672.x

Pfeffer, J. (1987). A resource dependence perspective on inter-organizational relations. In M. S. Mizruchi, \& M. Schwartz (Eds.), Interoperate relations: The structural analysis of business (pp. 22-55). Cambridge, UK: Cambridge University Press.

Premuroso, R. F., \& Bhattacharya, S. (2007). Is there a relationship between firm performance, corporate governance, and a firm's decision to form a technology committee? Corporate Governance, 15(6), 1260-1277. http://dx.doi.org/10.1111/j.1467-8683.2007.00645.x

Reddy, K., Locke, S., \& Scrimgeour, F. (2010). The efficacy of principle-based corporate governance practices and firm financial performance: An empirical investigation. International Journal of Managerial Finance, 6(3), 190-219. http://dx.doi.org/10.1108/17439131011056224

Reinard, J. (2006). Communication research statistics (p. 600). Thousand Oaks, CA: Sage.

Saibaba, M. D., \& Ansari, V. A. (2011). Audit committees and corporate governance: A study of select companies listed in the Indian bourses. The IUP Journal of Accounting Research \& Audit Practices, X(3), $1-10$.

Shivdasani, A., \& Zenner, M. (2002). Best practices in Corporate Governance: What two decades of research work? New York: Salomon Smith Barney.

Shleifer, A., \& Vishny, R.W. (1997). A survey of corporate governance. Journal of Finance, 52(2), 737-783. http://dx.doi.org/10.1111/j.1540-6261.1997.tb04820.x

Stanwick, P. A., \& Stanwick, S. (2010). The relationship between corporate governance and financial performance: An empirical study of Canadian firms. The Business Review, 16(2), 35-42.

Swamy, V. (2011). Corporate governance and firm performance in unlisted family owned firms. Working papers series, 4(2), 37-52.

Vafeas, N. (2005). Audit committees, boards, and the quality of reported earnings. Contemporary Accounting Research, 22(4), 1093-1122. http://dx.doi.org/10.1506/1QYN-2RFQ-FKYX-XP84

Wei, G. (2007). Ownership structure, corporate governance and company performance in China. Asia Pacific Business Review, 13(4), 519-545. http://dx.doi.org/10.1080/13602380701300130

Xu, L. C., Zhu, T., \& Lin, Y. (2005). Politician control, agency problems and ownership reform: Evidence from China. Economics of Transition, 13(1), 1-24. http://dx.doi.org/10.1111/j.1468-0351.2005.00205.x

Yasser, Q. R., Entebang, H., \& Mansor, S. A. (2011). Corporate governance and firm performance in Pakistan: The case of Karachi Stock Exchange (KSE). Journal of Economic and International Finance, 3(8), 482-491.

\section{Copyrights}

Copyright for this article is retained by the author(s), with first publication rights granted to the journal.

This is an open-access article distributed under the terms and conditions of the Creative Commons Attribution license (http://creativecommons.org/licenses/by/3.0/). 